\title{
Students' Disinterest in Taekwondo: A Phenomenological Study
}

\author{
Mark Fontanoza* \\ a mark.fontanoza @evsu.edu.ph \\ Eastern Visayas State University, Salazar St, Tacloban City 6500, Philippines
}

\begin{abstract}
Taekwondo is a subject offered for secondary students in Eastern Visayas State University taking PATHFIT 222 in consonance of the New General Education (CMO $20 \mathrm{~s}$. 2013) curriculum in providing holistic development of students and life long active lifestyle. However, it was observed that there are students who are not interested in taking Taekwondo as a Physical Education specialized sport. In this paper aims to explore the reasons why some students enrolled in Physical Education, specifically in Taekwondo who are not interested with the said sports even though it offers great benefits. This study utilized the Phenomenology - Qualitative research method through conducting an interview. There were Ten (10) selected respondents disinterested taekwondo. This paper concludes that students are unmotivated to learn because they do not see themselves as Taekwondo practitioners and want more fun in team sports. Students, on the other hand, purposefully refused to learn Taekwondo because they found it tiring and expensive as well. Furthermore, they have experienced or witnessed the high risk of injury caused by full contact sparring and are afraid to do so again. Moreover, students understand that participating in taekwondo makes them physically fit. They also believed that these benefits included enhance physical fitness and the development of stronger bones and muscles. Finally, based on the findings from student responses, it was discovered that participating in Taekwondo helps not only the physical aspect but also holistically such as self-discipline, self-confidence, and selfdefence.
\end{abstract}

Keywords: Disinterest; Taekwondo; Physical Education; Phenomenological; Martial Arts

\section{Introduction}

Physical activity, as well as participation in Physical Education and Sports, is the most effective strategy to achieve a healthy body and mind. "A sound body is a sound mind," stated both the Greek philosopher Thales and the Roman poet Juvenal, elaborating that a sound body is a healthy, physically fit body, and a sound mind is a mind capable of wonderful, happy thoughts. It is stated that achieving a sound body by successfully engaging in physical activities and assigning tasks to each muscle in the body leads to a sound mind, and that preserving bodily and mental harmony is the only way to live a healthy existence. 
People engage in sports for a variety of reasons and in a variety of ways. It's a task that demands both skill and procedure (Steinberg, 2020). Some people participate in sports to meet their requirements, maintain a healthy lifestyle, socialize, and earn money. Sports are secondary to oxygen in keeping a happy and healthy lifestyle, according to Khan et al. (2014). Sports are growing in popularity around the world because they provide a venue for competing, avoiding stress, and making new friends. Taekwondo provides a number of advantages and benefits. It's a type of self-defense that aims to develop the body, mind, and spirit (Petrovic, 2017).

Taekwondo requires physical or body mobility because it is a martial art that uses hands and feet. Taekwondo has been shown to be good to the body and fitness in some research. It improves and builds good body structure, according to Weiss and Miller (2019). Muscle improvement will occur through physical mobility and exercise before and after practices. Another study backs up the assertion that it enhances kids' balance and reaction time (Dijk et al., 2014).

Despite the numerous advantages that practicing Taekwondo can provide, many pupils remain uninterested in the discipline. Contusions, fractures (from falling), hyperextension of the joints, nosebleeds, sprains, and strains, like any other physical exercise, represent a danger of injury, which is a prevalent fear among students. Some children with health conditions, such as asthma, are also hesitant to participate in these games because they may harm them physically. Other pupils believe they are old and that their muscles are too stiff to stretch and do high kicks. These are some of the reasons why students are uninterested in the sports mentioned, and with this in mind, the researcher was motivated to conduct the study in order to learn more about the specific reasons why some students enrolled in physical education, specifically Taekwondo, are uninterested in participating in the sport. This objective guides the researcher's goal, which is to promote the benefits and advantages of Taekwondo. It will help students understand and appreciate Taekwondo.

\section{Theoretical Framework}

This study was anchored to these theories: Individual Differences Learning Theory of Karl Pooper, Behaviorism Learning Theory of Ivan Pavlov and Social Learning Theory of Albert Bandura.

Individualism is the foundation of this research. It was used to explore the study's various themes and show the students' reasons for not being interested in taekwondo. Solo variances were discovered, and it was discovered that some students prefer team sports like basketball to individual sports like Taekwondo. Some people were put off by the prospect of being hurt and were discouraged from fighting. As a result, students' preferences for second-year Physical Education disciplines, such as dance or sports, are stressed.

The main theory was further supported with the Behaviorism learning theory, which was used to apply particular stimuli together. Students noticed negative aspects of taekwondo, such as the high danger of injury, the fact that it is tiring and expensive, and that they dislike sparring sessions and are uninterested in the sport. The reason for this is because students have a negative reaction to what they see, which has a substantial impact on their ability to learn. When a learner learns to accept new things in his surroundings, learning and adaptability become much easier. As a result, a campaign or commercial showcasing the benefits and advantages of Taekwondo should be produced in Physical Education taekwondo programs where students have demonstrated apathy due to misconceptions. Students who are inspired by sports and driven to pursue taekwondo might benefit greatly from social media marketing such as Facebook and YouTube vlogs.

Finally, the Social Learning Theory proposes that people learn through watching others (models). The influence of those behaviors is then assessed by learners by seeing the good and negative outcomes. Even if they dislike the sport they have chosen, being in a group, being challenged by some advanced learners, and being motivated by their classmates and instructor pushes them to appreciate and continue doing the activity gladly and enthusiastically. External variables such as peer pressure and social media trends have an impact on learning a new sport.

These theories are intertwined to create a positive and successful study. It supports each other giving 
it a stronger impact and a viable result.

\section{Methodology}

Qualitative research, in general, is a sort of study that collects non-numerical data in order to analyze meanings. It aids with the comprehension of social life by examining certain populations or locations. Observation, immersion, interviews, open-ended surveys, focus groups, content analysis of visual and textual sources, and oral history are some of the methods used (Crossman, 2019). An interview was used in the study as a qualitative research method. The study's main goal is to figure out why students in physical education aren't interested in Taekwondo, as well as the benefits and advantages of the sport.

Moreover, since there is no previous data or only a few studies to refer to, exploratory research is used. It is a tool for preliminary study that delivers hypothetical research data. It necessitates the researcher to look into a variety of sources, including observations of research items and opinions on a company, product, or service (SMstudy, 2016). Exploratory research is performed in this study to determine why kids lose interest in Taekwondo and switch to other sports.

Furthermore, phenomenology is a qualitative research approach that focuses on the shared experience of a group of people. The approach's main purpose is to come up with a description of the phenomenon's nature (Creswell, 2013). The data in this study is presented using phenomenology research, which identifies themes from the students' replies on the reasons for their disinterest and the advantages and benefits of Taekwondo. To construct meaning clusters and arrive at a deeper understanding phenomenon.

\section{Results and Discussions}

The findings demonstrate that the students are uninterested in taekwondo. Less popular sport, health concern, high danger of injury, exhausting sport, less fun sport, expensive sport, less favored sport, and confrontational sport (sparring session is feared - kyorugi) are some of the reasons that come up. Despite this, students recognize the advantages and benefits of taekwondo, which include self-defense, the development of self-discipline and other positive traits, the development of self-confidence, the promotion of improved health, and the enhancement of physical fitness.

It also highlighted the significance of student motivation. Students are aware of the benefits and advantages of Taekwondo, yet many refuse to participate owing to a lack of motivation. Other pupils, however, are interested in learning more about the advantages and benefits of taekwondo.

\section{Acknowledgements}

The researcher wishes to express his sincere appreciation and gratitude to the following individuals for their support and inspiration that made this possible. Dr. Dennis C. De Paz., University President; Dr. Dominador O. Aguirre Jr., Former University President, Dr. Fatima Socorro M. Quianzon., Dean of College of Arts and Sciences of Eastern Visayas State University, for their encouragement to undergo further study.

The chairperson of the Committee on Oral Examination, Dr. Lydia M. Morante, Dean of the Graduate School, and panel members: Dr. Ma. Belinda C. Lora, faculty, Eastern Visayas State University Graduate School; Dr. Rosemarie C. Abocot, faculty, Eastern Visayas State University - Graduate School; and Prof. Joel A. Alfarero, OIC-Principal of Eastern Visayas State University - Laboratory School Department for their constructive criticism, expertise and guidance.

Dr. Erwin Oscar P. Ripalda, his adviser, for his expertise and guidance in this study; His parents, Guillerma and Lucilo Sr., who served as his inspiration and support; Dr. Senen Jude Javier A. Ruetas and Prof. Jerry Mores for their support and constant encouragement. Dr. Ryzel Maureen Canes, for her sisterly bracing, expertise and enlightenment. Ms. Jinky Alapoop, his assistant interviewer, for giving her time to 
make the interview possible. Amelita, Erickson, Val and to all Physical Education Faculty of Eastern Visayas State University, for the unceasing support and constant motivation.

Ed, Gualberto, Angelo and the rest of his churchmates, for the brotherly support and encouragement. Janyzza, Nikki and to the rest of all the MAED classmates, for the motivation. The Physical Education students, his participants of this study, who made this study possible. Special thanks to Iamebelle, for all her love and support.

Above all to the Almighty God, for giving astute wisdom and good health that kept the researcher on the go and determined to complete the study.

\section{References}

Armstrong, N. (2013). Taekwondo: The Unity of Body, Mind and Spirit. Seoul Selection.

Bandura, A. (1997). Self-efficacy: The Exercise of Control. New York. Retrieved from: https://psycnet.apa.org/. Accessed 15 July 2021.

Betti, M., \& Zuliani, L. (2002). School Physical Education: A Proposal of Pedagogical Guidelines. Mackenzie Magazine of Physical Education and Sports. vol. no. 1. pp. 73-81. Retrieved from: https://www.mackenzie.br/. Accessed 15 July 2021.

Brandolin, F. (2015). Students' Perception of Physical Education in High School. Journal of Physical Education. UEM. vol. 26. no.4. pp. 601, Doi: 10.4025/reveducfis.v26i4.29836. Retrieved from: https://www.scielo.br/. Accessed 15 July, 2021.

Braun, V., Clarke, V. (2012). Thematic Analysis: A Reflective Approach. American Psychological Association. vol. 2. pp. 55-71. Retrieved from: https://www.researchgate.net/. Accessed 19 July 2021.

Burhanudddin, N., Ahmad, N., Said, R., \& Asimiran, S. (2021). Learning Theories: Views from Beha viorism Theory and Constructivism Theory. International Journal of Academic Research in Progressive Education \& Development. vol. 10, no. 1, pp. 85-98. Retrieved from: https://hrmars.com/. Accessed 13 July 2021.

Cardoso, A. (2014). Perception of High School Students in Relation to Physical Education Classes. Physical Education Research Collection. vol. 13, no. 4, pp. 125-132. Retrieved from: https://www.nucleodoconhecimento.com.br/. Accessed 15 July 2021

Caulfield, J. (2020) How to Do Thematic Analysis. Scribbr. Retrieved from: https://www.scribbr.com/. Accessed 19 July 2021.

Challenge Martial Arts Centre. (2020). Coping with Anxiety Martial Arts. Martial Arts Website. Australia. Retrieved from: https://oakleighmartialarts.com/. Accessed 10 Jan. 2020.

Cho, I., Park, H., \& Lee, T. (2018). The Influence of Taekwondo Training on School-Life Adaptation and Exercise Value in The United States. Journal of exercise rehabilitation. vol. 14,2 213-218. doi:10.12965/jer.1836006.003, Retrieved from: https://www.ncbi.nlm.nih.gov/. Accessed 28 Jan. 2021.

Cresswell, J. (2013). Qualitative Inquiry \& Research Design: Choosing Among the Five Approaches. California, SAGE Publications, pp.103-106. Retrieved from: https://us.sagepub.com/. Accessed 13 July 2021.

Crossman, A. (2019). An Overview of Qualitative Research Methods. ThoughtCo. Retrieved from: https://www.thoughtco.com/. Accessed 5 April 2021.

Dan, Y., Hirsch, G. (2013). The Five Tenets of Taekwondo. Hwa Rang Kwan Napa. Retrieved from: https://www.hrknapa.com/. Accessed 15 July 2021.

Dijk, G., Lodder, J., \& Leffers, P. (2014). The Effectiveness of Hard Martial Arts in People Over Forty: An Attempted Systematic Review. Societies. Vol. 4, pp. 161-179. Research Gate, doi:10.3390/soc4020161. Retrieved from: https://www.researchgate.net/. Accessed 22 June 2021. I

Frankin Family of Taekwondo. (2017). Physical Fitness Benefits of Taekwondo. 454 Downs Boulevard. Suite. Retrieved from: https://www.franklinfamilytkd.com/. Accessed 6 Jan. 2021.

Fuller, C., Lloyd, V. (2020). Martial Arts and Well-Being. Oxon.

Greenleaf, C., Boyer, E., \& Petrie, T. (2009). High School Sport Participation And Subsequent Psychological Well-Being And Physical Activity. Spring Science. vol. 21,, pp. 714-726, Washington, DC, doi: 10.1007/s.11199-009-9671-z. Retrieved from: https://psycnet.apa.org/. Accessed 15 Feb. 2021.

Holden, S., Schwarz, N. (2017). Achievement Motivation for Collegiate Athletes for Sports Participation, International Journal of Sports. vol. 7. no. 2. pp. 25-28, Research Gate, Retrieved from: https://www.researchgate.net/. Accessed 22 April 2021.

Hong Ik Martial Arts. (2016). The Trinity of Taekwondo: Body, Mind, and Spirit. Sisun Communication Arts. New York. Retrieved from: https://hongikmartialarts.com/. Accessed 10 Dec 2020

Iso-Ahola, S., Park, C. (2017). Leisure-Related Social Support and Self-Determination as Buffers of Stress-Illness Relationship. Journal of Leisure and Research, vol. 28, Issue 3. pp. 169-187. doi.org/10.1080/00222216.1996.11949769, Retrieved from: https://www.tandfonline.com/. Accessed 10 June 2021.

Jalnawala, N. (2017). TAEKWONDO: An Introduction. Retrieved from: http://jalnawala.com/. Accessed 22 Nov. 2020.

Jett Martial Arts. (2019) Why Study Taekwondo?. Retrieved from: https://www.jettma.com/. Accessed 16 Feb. 2021.

Ji, M. (2016). Analysis of Injuries in Taekwondo Athletes. Journal of Physical Therapy Science. vol. 28, Issue 1. pp. 231-234. doi:10.1589/jpts.28.231, Retrieved from: www.ncbi.nlm.nih.gov/. Accessed 5 July 2021.

Kasper, K. (2019). Sports Training Principles. Current Sports Medicine Reports. vol. 18, Issue 4. pp. 95-96. American College of Sports 
Medicine, doi: 10.1249/JSR.0000000000000576. Retrieved from: journals.lww.com/. Accessed 24 June 2021.

Khan, M., Farhatullah, P., Khan, I., \& Phil, F. (2014). The Importance of Sports and the Role of the Institutional Head. IISTE, vol. 14, no. 11. ISSN: 2224-5758. Retrieved from: https://www.researchgate.net/. Accessed 28 May 2021.

Kim, (1979). Taekwondo Defense Against Weapons. YMAA Publication Center.

Kim, B. (2012). Taekwondo-A Powerful Tool for Self-defense. YMAA Publication Center. Retrieved from: https://ymaa.com/. Accessed 15 May 2021.

Kim, J., Heo, J., \& Dattilo, J. (2017). Taekwondo Participation as Serious Leisure for Life Satisfaction and Health. Journal of Leisure and Research. vol. 43, Issue 4. pp. 545-559 DOI:10.1080/00222216.2011.11950249. Retrieved from: https://www.researchgate.net/. Accessed 19 June 2021.

Kusnierz, C. (2011). Values Associated with Practicing Modern Karate as Form of Cultivating Old Japanese Bushido Patterns. Ido Movement for Culture Journal of Martial Arts Anthropology. vol. 11, no. 4. pp.1-5. Retrieved from: https://bazhum.muzhp.pl/. Accessed 16 May 2021.

Law, D. (2020). A Choice Theory Perspective on Children's Taekwondo. International Journal of Reality Therapy. vol. 24, issue 4. pp. 13-18. Retrieved from: http://wikifoundryattachments.com/. Accessed 16 May 2021

Lakes, K. (2013). The Value of Youth Education in Taekwondo Training: Scientific Evidence for the Benefits of Training Children. Taekwondo J Kukkiwon. Vol. 4, pp. 101-120.

Lee, B., Kim, K. (2015). Effect of Taekwondo Training on Physical Fitness and Growth Index According to IGF-1 Gene Polymorphism in Children. Korean J. Physiol Pharmacol. vol. 19, no. 4. pp. 341-347, Daegu, Retrieved from: https://synapse.koreamed.org/. Accessed 27 May 2020.

Legend Mixed Martial Arts. (2017). Mental and Physical Health Benefits of Taekwondo. G Web Pro. Retrieved from: https://legendsmma.net/. Accessed 22 Dec. 2020.

Level Up Taekwondo. (2018). 13 Benefits of Taekwondo That Will Make You Want Your Black Belt. Retrieved from: https://leveluptaekwondo.com/. Accessed 28 July

Lim, B. Kim, K. (2011). Peer Relationship's Network Structure and Decisive Factors Analysis of Peer Status Among the Children Participating in Sports Club. Korean J Sociol sport. Retrieved from: https://scholar.google.com/. Accessed 29 May 2021

Luke, S. (2020). Individualism: Politics and Philosophy. Britannica. Retrieved from: www.britannica.com/. Accessed 1 July 2021.

Master Chong's World Class Taekwondo. (2021). What is Taekwondo? Retrieved from: https://buffalotkd.com/. Accessed 17 Feb. 2021.

Ming, J. (2021). How to Eliminate Students' Psychological Fear in Physical Education. China National Knowledge Infrastructure. Retrieved from: https://en.cnki.com.cn/. Accessed 7 March 2021.

Monika, T. (2020). World of Para Taekwondo/ Training in the Garden. Honorary Reporters. Retrieved from: https://www.korea.net/. Accessed 15 July 2021

Mosler, D. (2018). Application of Taekwondo Paralympic Rules for Sparring Competition in Terms of Special Needs Physical Education for Reduction of Challenging Behaviour. Society Integration Education Proceedings of the International Scientific Conference. vol. 3. doi:10.17770/sie3419. Retrieved from: https://www.researchgate.net/. Accessed 27 March 2021.

Naves-Bittencourt, W., Sousa, A., Stults-Kolenmainen, M., \& Fontes, E. (2015). Martial Arts: Mindful Exercise to Combat Stress. European Journal of Human Movement. vol. 34. pp. 34-51. Retrieved from: https://www.researchgate.net/. Accessed 5 Nov. 2020.

Park, D., Shein, A. (2006). Taekwondo: Indomitable Martial Art of Korea. Invisible Cities Press LCC. Korea

Parsons, E., Betz, N. (2001). The Relationship of Participation of Sports and Physical Activity to Body Objectification, Instrumentality and Locus of Control Among Young Women. Blackwell Pulishers. vol. 25. pp. 209-222. Retrieved from: https://files.eric.ed.gov/. Accessed 15 March 2021.

Pavlov, I. (1902). The Work of the Disgestive Glands. London. Griffin.

Petrovic, K. (2017). The Benefits of Taekwondo Training for Undergraduate Students: A Phenomenological Study. MDPI Journals. vol. 7, issue 3. pp. 1-20. doi.org/10.3390/soc7030027. Retrieved from: https://www.mdpi.com/. Accessed 5 May 2020.

Philosophy. (2021). Taekwondo: Body, Mind, and Spirit. Retrieved from: https://www3.nd.edu/ wtfclub/philo.html

Pinheiro, M., Pinheiro, G., Noce, F., \& Andrade, A. (2015). Motivational Dimensions of Taekwondo Practitioners. Science of Martial Arts, vol. 11. pp. 402-411, Research Gate, https://www.researchgate.net/. Accessed 5 Jan. 2021.

Potenza, G., Yu, J., Konukman, F., \& Gumusdag, H. (2014). Teaching Self-Defense to Middle School Students in Physical Education. Journal of Teaching in Physical Education. vol. 85, no, 1. pp. 47-50. doi: 10.1080/07303084.2014.855581. Retrieved from: https://www.researchgate.net/. Accessed 5 Feb. 2021.

Pottle, B., Pottle, K. (2013) Taekwondo: A Practical Guide to the World's Most Popular Martial Art. United States of America.

Rowchowdhury, D. (2016). Functional Significance of Participation Motivation on Physical Activity Involvement, Psychological Thought. vol. 11, no. 1. pp. 9-17, Australia. Smstudy. Exploratory Research Design. Retrieved from: https://www.smstudy.com/. Accessed 10 May 2021.

Shaw, S. (2014). Mindfulness Mechanisms and Stress Level During A Mind-Body Intervention: An Eight Week Correlation Study of Taekwondo Practitioners. ProQuest Dissertations Publishing. Arizona. UMI Number: 3615871, Retrieved from: https://www.proquest.com/. Accessed 20 Dec. 2020.

Schwartz, S. (2012). An Overview of the Schwartz Theory of Basic Values. Online Reading in Psychology and Culture. vol. 2, no. 1. pp. 1-20, Retrieved from: https://scholarworks.gvsu.edu/. Accessed 19 May 2021. 
SMstudy. (2016). Exploratory Research. Marketing Research. Retrieved from: https://www.smstudy.com/. Accessed 4 April 2021.

Spencer-Cavaliere, N., Rintol, M. (2012). Alienation in Physical Education from the Perspectives of Children. Journal of Teaching in Physical Education. vol. 31, no. 4, p. 344-361, DOI:10.1123/jtpe.31.4.344. Retrieved from: https://www.researchgate.net/. Accessed 15 July 2021

Stainko, D. (2017). Martial Arts Exercises Good for Asthma Patients. Learning Center. Retrieved from: https://www.usadojo.com/. Accessed 13 July 2021

Steinberg, L. (2018). What Defines a Sport?. Retrieved from: https://www.forbes.com/. Accessed 17 July 2020.

Steward, Brian. (2021). Taekwondo for Physical Fitness, Colorado Taekwondo. Retrieved from: https://www.coloradotaekwondo.com/. Accessed 13 July 2021.

Taekwondo Nation. (2020). What are the Health Benefits of Taekwondo?. Retrieved from: https://www.taekwondonation.com/. Accessed 20 March 2021.

The Ontario Curriculum. (2019). Health and Physical Education. Queens Printer for Ontario. Retrieved from: http://www.edu.gov.on.ca/. Accessed 28 July 2021

Thomas, T. (2015). How Martial Arts Can Positively Change Lives. Library of Congress Cataloging-in-Publication Data.

Tipane, J. (2021). What are the Mental and Physical Health Benefits of Exercise. Medical News Today. Retrieved from https://www.medicalnewstoday.com/articles/benefits-of-exercise. Accessed 28 July 2021.

Twemlow, S., Lerma, B., \& Twemlow, S. (2016). An Analysis of Student's Reasons for Studying Martial Arts. SAGE Journals. Retrieved from: https://doi.org/10.2466/pms.1996.83.1.99, ISSN: 0031-5125. Retrieved from: https://pubmed.ncbi.nlm.nih.gov/. Accessed 5 June 2021.

USA Taekwondo. (2014). Poomsae Competition Rules. Retrieved from: www.teamusa.org/. Accessed 13 July 2021.

VIA Institute of Character. (2021). Love of Learning. Retrieved from:https://www.viacharacter.org/. Accessed 26 May 2021.

Weiss, E., Miller, J. (2019). Training the Body and Mind: Examining Psychological Correlates of Taekwondo. International Journal of Martial Arts. Research Gate, Retrieved from: www.researchgate.net/. Accessed 2 June 2021.

World Martial Arts Academy. (2021). Taekwondo Benefits, World Martial Arts Academy of St. Peters. GR Morris Web of Productions. Retrieved from: https://www.worldtaekwondo.com/. Accessed 15 Dec. 2020.

World Taekwondo. (2017). Statutes.

Xingang, L. (2021). The Cause and Solution of Fear Occurred in Taekwondo Competitions. China National Knowledge Infrastructure. Retrieved from: www.en.cnki.com.cn/. Accessed 25 May 2021.

Zeng, H., Cynarski, W., Baatz, S., \& Park, S. (2015). Exploring Motivations of Taekwondo Athletes/Students in New York City. World Journal of Education. vol. 5, no. 5. doi:10.5430/wje.v5n5p51, Retrieved from: http://www.sciedupress.com/. Accessed 21 June 2021. 